\title{
INTERDEPENDENCE BETWEEN HUMAN CAPITAL AND THE POWER OF A SHADOW ECONOMY: LITHUANIAN CASE STUDY
}

\author{
Rūta ČIUTIENĖ, Evelina MEILIENĖ, Asta SAVANEVIČIENĖ, \\ Sigitas VAITKEVIČIUS \\ Department of Management, Kaunas University of Technology, \\ K. Donelaičio g. 73, LT-44029 Kaunas, Lithuania
}

Received 17 March 2014; accepted 18 January 2015

\begin{abstract}
According to economic theory, economic growth is related to Human Capital (HC). Lithuania is associated with countries where a high level of shadow economy exists. This paper examines the issues of human capital development under conditions of shadow economy. The aim of this paper is to evaluate the power and effects of the Lithuanian shadow economy in the context of human capital and to assess the inter-dependence between the power of the shadow economy and human capital. The theoretical justification for research on the inter-dependence between the power of the shadow economy and human capital is based on the analysis of how changes in the human capital structure and indicators reflect the power of the shadow economy and vice versa. Theoretical analysis has been made on the main features and factors of shadow economy and possible tools of human capital evaluation. On the basis of theoretical findings, the model of shadow economy power has been created and using the linear regression method, the dependence of shadow economy power on human capital has been evaluated. The power of the shadow economy has been calculated as a function of population, GDP, trade, unemployment and the labor force. Variables of social development, such as demographic changes and risk of poverty, indicators of $\mathrm{HC}$ economic development and indicators of $\mathrm{HC}$ economic potential have been used for the research. For the evaluation of the interdependence of the variables, the years 2005-2012 were used. In evaluating human capital under the conditions of the shadow economy, a few periods have been identified and distinguished. Firstly, the results showed that the level of human capital education and unemployment can be described as the most important indicators that reflect the economic environment and shadow economy. Secondly, the increasing level of the shadow economy increases shadow unemployment, and this in turn influences the attraction of direct foreign investment. And finally, research on the influence of separate factors of the shadow economy on variables of human capital could disclose a deeper understanding of the impact of the shadow economy on human capital.
\end{abstract}

Keywords: human capital, shadow economy, power of a shadow economy.

JEL Classification: C52, E24, J24, O17.

Corresponding author Rūta Čiutienè

E-mail: ruta.ciutiene@ktu.lt 


\section{Introduction}

Undoubtedly, human capital (HC) is one of the most important drivers of economic growth. Countries that are characterized as having a strong and growing economy also exhibit a high value of human capital. According to the data of EUROSTAT, the dispersion of indices of GDP per capita in the EU member states makes this fairly clear. The highest GDP per capita is in Luxembourg, which exceeds the EU-27 average by more than two and a half times; in the Netherlands it exceeds the EU-27 average by 33\%; while in 2010, the GDP per capita of Denmark, Austria and Sweden exceeded the EU average by at least 20\% (Gasik 2011). According to the assessment of human capital by the World Economic Forum (2013), the human capital index of these countries falls among the world's twenty leading states. It is obvious that in striving for the growth of human capital and economic growth at the same time, favorable circumstances should be created. Unfortunately, the formation of a shadow economy often distorts these ideal circumstances.

A shadow economy exists in all countries, however, in one or another form it influences a country's economic development, the social welfare of its people and a country's policies, depending on the country's size. A shadow economy is a multi-faceted and ambiguously rated phenomenon that is determined by economic, psychological - social, legal and administrative factors as well as the peculiarities of cultural development and the citizens' moral. On the other hand, the expression of a shadow economy causes different effects on the social and economic welfare of the people. The question arises of how the manifestation of a shadow economy influences the formation of a country's human capital, and is such an assumption available at all? Scientific economic literature analyzes the problems of human capital in a very broad manner. In many cases, economists analyze human capital as a factor of a country's economic growth. Scientists study how investments in public education, health, constant learning and the use of IT are ensuring the growth of human capital. Unfortunately, human capital is a very sophisticated and hard to predict factor that is affected by environmental conditions in a complex complicates. The appearance of a shadow economy distorts the conditions where the means stimulating the growth of human capital are being applied. In scientific economic literature there is a lack of studies analyzing how a shadow economy affects human capital, and what should be done in order to reduce the negative influence on human capital.

The research of the problem is complicated by the fact that it is difficult to estimate the real extent of shadow economy. There are many formulas that have been created and proposed for estimating the size of a shadow economy which are quite different. Nevertheless, it should be noted that formulas for estimating a shadow economy may be lacking face and content validity. Besides, although they may satisfy a criterion of demarcation, there are no objective conditions for their evaluation from a point of view considering the possible falsification or invalidity of a criterion.

The goal of the paper is to evaluate the power of the shadow economy's manifestation within the context of human capital, and to assess the inter-dependence between the power of the shadow economy and human capital.

The paper analyzes the main factors of the shadow economy along with the theoretical, as well as methodological aspects of the assessment of the size and extent of their manifestation. The analysis of scientific literature that was performed has allowed a formula to be developed 
that permits the estimation of the amount and extent of a shadow economy's power. It was calculated as a function of population, GDP, trade, unemployment and the labour force. Using this formula, the estimated variable has made an assessment of the interdependence between human capital and a shadow economy possible. The study was financed by the Research Council of Lithuania (Institutional scientific research program - "Challenges of the Lithuanian economy's long-term competitiveness").

\section{Literature review on the shadow economy and human capital}

\subsection{Shadow economy: conception, factors and characteristics}

An officially unaccounted-for economy (unofficial or shadow economy) exists in all countries and in one or another way influences a country's economic development, the public social welfare and a country's policies, depending on a country's size. When a large unofficial or shadow economy is present in a country, the legal and taxation bases cannot be effective. The burden of taxation is increased for the officially accounted economy, while participants of the unofficial or shadow economy evade taxes, thus impoverishing the country's budget (Tafenau et al. 2010; Schneider 2010). Manufacturing, incomes and expenses that are not accounted for do not allow a precise evaluation of a country's economy state, and the formation of rational policies regarding economic development and regulation. Such an economy distorts the official statistics; therefore, policies that are based on it may become unreliable or simply irrational. All of this impedes or stops economic growth, so almost all countries try to limit the size of the unofficial or shadow economy.

Descriptions of a shadow economy presented in scientific literature highlight the same features of an officially unaccounted-for economy: values are created but not accounted for officially. Consequently, any economic activity that increases the total value of the product created in a country, but is not included in the national accounts and not shown while calculating gross domestic product can be attributed to a shadow economy.

Development of a shadow economy and its uneven volumes in different countries is determined by many factors and therefore, the actual influence of a shadow economy is often evaluated differently. Literature presents many different factors in determining the origin of a shadow economy and reasons that stimulate its growth and extent. Some authors propose that economic factors are the main ones (Kanao, Hamori 2010; Startiene, Trimonis 2010), while others (Alm, Torgler 2006; Edwards, Flaim 2008) highlight the importance of taxation morality (totality of the psychological, social and cultural peculiarities determining the behavior of participants within an economy) on the size of a shadow economy (Gomis-Porqueras et al. 2014; Torgler 2003; Sharpe 2007). The most often cited and the most important factors of a shadow economy are as follows:

- burden of direct and indirect taxation, compulsory social insurance fees and their increase;

- too strict (or insufficient) legal and administrative regulation, especially in the labour market;

- weak authorities and a high level of corruption present in the state sector; 
Less mentioned, but no less important factors of a shadow economy are as follows:

- imparity of incomes (high level of poverty);

- gaps in legal acts, limitations of the taxation administration system;

- irrationality of a country's economic policy;

- taxation morality;

- insufficient attention of authorities to social policies or their irrational development without proper consideration for social welfare, social security and the level of satisfaction of other social needs (Krumplyte 2008).

In analyzing the aspects of illegal labour and the evasion of income tax, the most often mentioned factors and reasons are as follows:

- limitation of legal labour relations determining the appearance of illegal labour;

- difference between labour costs and wages - the greater this difference, the larger the inducement to elude it by moving into a shadow economy.

The existence of a shadow economy disturbs the economy, raises chaos inside it, destroys the welfare of citizens and increases the dispersion of shadow economy products (Enste 2010). Usually, this is compensated for by increasing the taxes on honest taxpayers, increasing state debt or decreasing expenses. The largest portion of the shadow economy is based on cash money; therefore, it is supposed that where more cash than normal business needs require is circulating, more money is flowing into the shadow economy. Based on information on the circulating cash amount and other economic data, economists calculated that the shadow economy may reach from 5 to $15 \%$ of GDP. When the size of the shadow economy in a country exceeds $50 \%$, the situation in the country becomes out of control (Schneider, Enste 2002; Krumplyte, Samulevicius 2010). A shadow economy not only has a negative effect on a country's economic development, but on its social development as well. This is expressed in the growth of illegal labour and unaccounted income, development of social differentiation and distrust in the state as well as the growth of corruption (Okuneviciute Neverauskiene, Pocius 2011). The growth of a shadow economy also weakens a government's social policy as well. Decreasing the state's annual income decreases expenses dedicated to social needs, which in turn increases social differentiation. A shadow economy not only affects government, but society as well (Kanao, Hamori 2010; Schneider, Williams 2013). When a shadow economy is present, a certain percentage of the citizens have to pay taxes instead of those who are not paying. People who follow the laws regarding taxation are paying higher taxes than they should pay. In this manner, a budget deficit is being compensated for. People working in the shadow economy lose their social guarantees as well, because they do not declare their incomes and are not paying social insurance fees. A person who is receiving a high income from contraband activity, which is unknown to employees of the territorial job centers, can claim social allowances. The existence of a shadow economy decreases the level of real unemployment because a person who is unable to find job in the official economy usually finds it in the unofficial labour market. Growth of a shadow economy generally stimulates an increase in incomes. However, while working in the shadow economies, the cases of exploitation and the probability of injuries increase, because proper working conditions are often not present. 
A shadow economy decreases the average level of state productivity and thus, a country's growth. Contrary to common thought, empirical studies have shown that when the amount of official economic activity increases, the shadow economy grows as well. Therefore, a shadow economy causes social degradation as well.

The relationship of the unemployment level and the shadow economy has been researched quite actively. Bajada and Schneider (2009) present a model where they state "shadow economy work does typically increase during periods of declining legitimate economic activity (and therefore, increasing unemployment) as shadow economy work replaces work in the formal economy. The relationship tends to be symmetrical in that, as unemployment increases, shadow work increases and, as unemployment decreases, shadow work also decreases". Williams and Nadin (2012) raised the idea that "the unemployed disproportionately participate in, and gain from, undeclared work (the 'marginalization' thesis) and the 'reinforcement' thesis, which holds that the unemployed benefit less from undeclared work than those in declared employment, meaning that undeclared work reinforces, rather than reduces, the inequalities produced by the formal economy. Which of these explanations is valid is potentially an important policy issue".

Thus, a shadow economy negatively affects capability, activity and the behavior of a country's labour force. This influence affects human capital differently in the shadow economy sector and outside it. When a shadow economy is present in a country's economic growth and social development, human capital remains one of the most important factors. In striving to assess the influence of human capital on a shadow economy and its changes, the factors that need to be assessed have to be selected properly.

\subsection{Human capital concept, human capital index and determinants}

In economic literature, human capital is highlighted as the most important factor in determining economic growth more and more often (Nafukho et al. 2004). Economists and representatives of social sciences describe human capital as knowledge and skills, a country's or enterprise's labor force capabilities, and factors that create assumptions or possibilities for people to create innovations or strive for higher productivity. While talking about human capital, there is discussion about the challenges of how people can achieve productivity in their activities while at the same time warranting the growth of a country's economy or the growth of an enterprise (Blair 2012).

Application of the concept "human capital" had already started in the beginning of the last century. Researchers of human capital state that Arthur Pigou was the first economist who used this concept in 1928, and in 1937, Adam Smith was the first who raised the idea that human capabilities are a presumption of higher productivity. In 1964, Gary Becker examined the role of teaching and education during the formation of a labor force's knowledge and skills, thus grounding different possibilities for wages (Blair 2012).

According to the statements of Škare (2011), Perrons (2012) and Charles et al. (2011), there is a direct and positive relationship between human capital and the growth of an economy. Human capital is perceived as one of the most important factors of productivity. Further, the development of human capital is extremely sensitive to changes in the taxation 
of a workforce (Gillman, Kejak 2014) and life expectancy has a positive influence on human capital (Hansen 2013, Arendt 2012).

The World Economic Forum (2013) calculates an index of human capital that includes four main sub-indexes: Education, Health and Wellness, Workforce and Employment, and Enabling Environment. The Human Capital Index (HCI) is a tool for understanding where countries stand today, so that government and business can engage in workforce planning for the future.

The education sub-index includes indices allowing for the assessment of citizens' educational level (from primary to high education level), and the readiness of the labor force for future challenges. The sub-index of Education identifies the extent that access to education and the quality of education impact the future labour force and the educational attainment of those already in the labour force.

The sub-index of Health and Wellness includes indices that allow the assessment of citizens' physical and mental well-being. The four dimensions that are identified by Health and Wellness are: survival, health, well-being and services. The sub-index of Workforce and Employment includes indices that allow the assessment of experience, knowledge and the constant development of working age citizens. The Workforce and Employment sub-index identifies the extent of participation, talent and training. The sub-index of Enabling Environment is intended to assess assumptions of human capital development such as a country's legal system, infrastructure. The Enabling Environment sub-index also identifies the extent and size of the infrastructure, cooperation, legal system and social mobility (World Economic Forum 2013).

Sakalas and Liepe (2013), and Liepe (2013) adapted a methodology for the calculation of multifactor indices and constructed a complex human capital assessment system that establishes the social, innovation, and Economic Value Index, including the Cost Index and Income Index. According to the statement of the authors, it is necessary to select the indices during the assessment of human capital to allow a further assessment of the role of human capital in the growth of a country's economy. The methodologies of multifactor indices supplement and extend the methodology of the World Economic Forum human capital index calculation and the portfolio of the indices to be assessed. The content of the portfolio of human capital assessment indices has to be formed individually, depending on the context and the field of specific research (Ciegis et al. 2009), and based on economic logic.

\section{Methodology employed in the calculation of shadow economy power and its empirical verification}

The methodology of this study included two essential variables: the power of the shadow economy and the methodology of modeling its interdependence with human capital. In the methodology presented in this article, more attention is given to validation of the shadow economy power, because this is the first time that the equation of the shadow economy power, and results based on it, are being published. Therefore, it was important to first validate the results of the shadow economy power and to only then measure its interdependence with human resources capital. 


\subsection{Calculation model used to assess shadow economy power}

To date, there have been numerous attempts to calculate the size and extent of a shadow economy. Several formulas have been created and proposed that measure the scale of a shadow economy differently. However, it should be noted that the formulas concerning a shadow economy that are widely used, at least in Lithuania, are lacking in face and content validity. Besides, while they may satisfy a criterion of demarcation, there are no objective conditions for an evaluation of the falsification or invalidity of a criterion in its point of view. Up until now, economists have not reached a single agreement on how to calculate the exact scale of a shadow economy. Usually, such a situation has resulted in formulas that have had more of a political rather than economic meaning.

In trying to identify a relationship between human capital and a shadow economy, it was decided to not estimate the scale of shadow economy, but to instead estimate the power driving the formation of a shadow economy. The term power is chosen because according to the Oxford Dictionary of English (2005-2011), it means "the capacity or ability to direct or influence the behaviour of others or the course of events". In our case, the developed coefficient estimates the degree to which a shadow economy is likely to occur due to the changes in the economics of a country and the well-being of its people.

The power, instead of the size or scale, has been chosen first of all because of the ability to measure the shadow economy. It is impossible to measure the scale or size because of the nature of the shadow economy. It would not be a shadow economy if the possibility to measure it existed. Up until now, many attempts to measure the size or scale of a shadow economy have been made, but each formula has raised more questions than answers.

The second reason why this paper uses the name power instead of size or scale is because a shadow economy is also an economy, and in learning about its behavior, it will also be possible to control it. The formula that has been developed is designed to study the economic behavior of a population, not the size or scale of the shadow economy.

We think that a shadow economy represents the level of trust that a population has in its economic laws and governance. If the people are satisfied with their economic laws and governance, the level of their shadow economy should be low, but if the people are dissatisfied with their economic laws and governance, they will tend to behave under the terms of a shadow economy. For example, it's possible that when the people believe that the government does not give enough in return for the taxes it is paid, that this will lead to an increase in the shadow economy. But if the people believe that they get enough from the authorities for the taxes paid, the shadow economy will shrink. This is the main reason why this paper is looking for variables that will explain change in a shadow economy, and this would also allow measurement of the economic well-being of the people.

The third argument supporting the choice of the word power instead of size or scale was the findings from previous research indicating that the size or scale of shadow economics is sensitive to changes in the legislative basis and to changes in social opinion (Operational programme for... 2007). This means that countries with a better-developed legislative framework and a more advanced society, which adheres to ethical norms and standards, are more resistant to a shadow economy. These are the reasons why power was chosen to estimate the shadow economy instead of size or scale. 
The power of the shadow economy can be calculated as a function of population, GDP, trade, unemployment and the labor force. The formation of such a function allows evaluation of the condition of human capital in relation with the main economic indices. Besides, during the sequence of economic events that occurred in 2008, it was observed that the main feature of the phenomenon under consideration was that the power of the shadow economy theoretically increases when the level of the GDP and labour force decreases and the unemployment rate increases. Trade and population were selected as indices in evaluating market size. In such a way, an equation was developed to estimate the power of a shadow economy $r_{S e_{i}}$ :

$$
r_{S e_{i}}=\frac{G 47_{i} \cdot B_{i}}{\left(1-\frac{D_{i}}{G_{i}}\right) \cdot D_{i} \cdot B V P_{i}},
$$

where: $G_{i}$ - Population at the beginning of the year; $B V P_{i}-$ GDP at current prices, LTL; $G 47_{i}$ - G47 Trade, except trade in engine vehicles and motorcycles, LTL; $B_{i}$ - Number of persons registered as unemployed; $D_{i}$ - Labor force.

Preliminary estimations that were performed showed that the calculation model can be characterized by its reactivity to the economic changes that are taking place (Fig. 1). A more detailed analysis of the figure showed that the level of the shadow economy power in Lithuania reached a peak in its growth in 2010. Since then, the power of the shadow economy has been decreasing.

In assessing the change in the growth rate of the shadow economy power (Fig. 2) in Lithuania, it was noticed that a jump in the shadow economy power occurred in 2009 . This leads to the conclusion that the calculation model, from a phenomenological point of view, is characterized by its relative ecological validity.

The growth rate of the shadow economy power is estimated using the formula:

$$
G_{r}=\frac{y_{i}}{y_{i-1}}-1 \text {, }
$$

where: $y_{i}$-Current period; $y_{i-1}$ - Previous period.

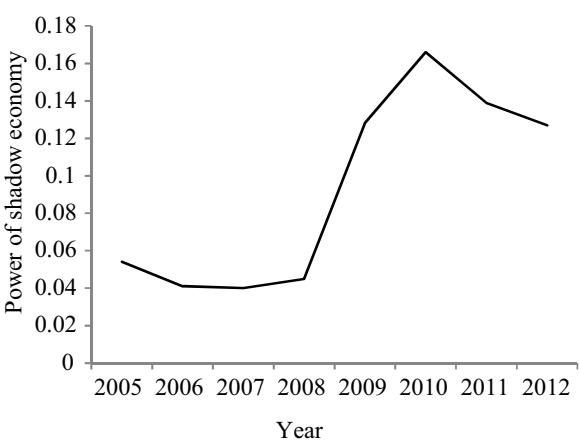

Fig. 1. Dynamics of shadow economy power in Lithuania

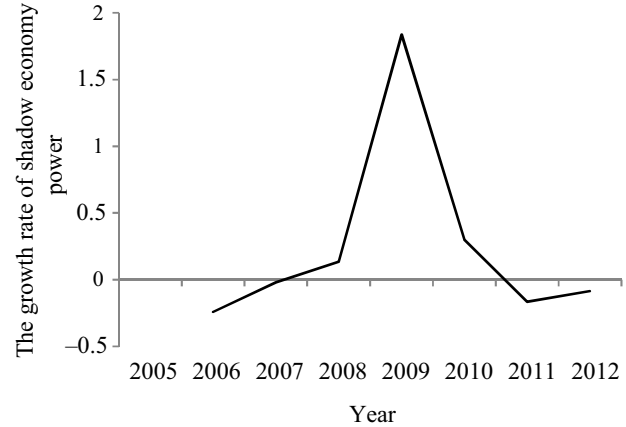

Fig. 2. Growth rate of shadow economy power in Lithuania 
The use of the equation in countries having various levels of a shadow economy would not only allow evaluation of the qualitative - phenomenological correctness of the shadow economy power calculation model, but also gather statistical evidence about the extent of its ecological validity.

\subsection{Methodology employed in the empirical verification of shadow economy power in Lithuania}

During the research, not only the ecological validity was evaluated. Other forms of validation, like convergent validity, which was obtained by comparing the index with objective indicators of shadow volume, and predictive validity were also evaluated.

For assessment of validity, methods of linear regression analysis and trend analysis (linear and polynomial) were used. The results of regression analysis were verified using a standard set of quality indicators - SPSS v20.0 (license holder: Kaunas University of Technology). The reliability of the linear and polynomic trend projections was evaluated, calculating the bias of approximation $-\mu$. It was supposed that if the bias of approximation does not exceed $5 \%$ for a trend projection, that the retrospective prognostic model could be used for perspective prediction. Calculation of a trend projection was performed using the MS Excel 2010 program (license holder: Kaunas University of Technology).

\subsection{Results of the assessment of the empirical validity of shadow economy power in Lithuania}

Results of the assessment of the convergent and discriminant validity of shadow economy power. Convergent validity was measured by comparing the shadow economy power with three variables: Criminal offences related to the possession of narcotic or psychotropic substances and their contraband (crimes), Criminal offences related to the possession of narcotic or psychotropic substances and their contraband (misdemeanors) and distribution of households in the Republic of Lithuania in accordance to the households' ability to make ends meet (live without poverty).

The first two variables were selected because they show an objective level of the shadow economy or in other words, consequences. It should be noted that Lithuanian public statistics only present three variables that have a clear relation to the shadow economy. They are all related to narcotic contraband and illegal use. These variables were deliberately evaluated in this study because, first of all, narcotics only create a shadow economy in Lithuania because they are prohibited and cannot be officially evaluated. Besides, this is a product whose use is related to dependence illnesses, which likely forms its exceptional characteristics as a variable. Nevertheless, during the research, the provision has been followed that in the point of view of a macro-system, when a break in economic evolution happens, this variable shows a change in the level of the shadow economy because we suppose that when the preventive means applied in this area decrease during economic turmoil, entrepreneurship in this business increases. Because of this reason, the activity itself becomes more visible and as a result, more such cases are registered. It is likely that other businesses of the shadow economy develop 
in an analogous way. Therefore, not only were these variables themselves important during this research, but also their behavior.

The third variable was selected because it possibly determines reasons. It should be noted here that during the research, the notion was followed that people, whether business or private, tend to avoid paying taxes because of two essential reasons: the first - according to their opinion, was that the taxes paid do not create sufficient additional value, and are therefore not worth paying, and second - that there is an attempt to earn and maximize incomes. The other taxonomic reason possibly determines the identity of the named and is a form of expression of their identity.

For measurement of convergent validity between criminal offences and the variable of calculated shadow economy power, a linear regressive analysis was used (Tables 1, 2 and 3). Comparative measurement was performed for the period of 2005-2012.

Table 1. Descriptive statistics of the variable of shadow economy power and criminal offences in 2005-2012

\begin{tabular}{llccc}
\hline \multirow{2}{*}{ Variable type } & \multicolumn{1}{c}{ Variables: } & \multicolumn{3}{c}{ Descriptive statistics } \\
\cline { 3 - 5 } $\begin{array}{l}\text { Dependent } \\
\text { Variable }\end{array}$ & Power of shadow economy & Std. Deviation & $\mathrm{N}$ \\
\hline & $\begin{array}{l}\text { Criminal offences related to the possession of } \\
\text { narcotic or psychotropic substances and their } \\
\text { contraband (crimes) }\end{array}$ & 1554.75 & 365.19887 & 8 \\
\cline { 2 - 5 } $\begin{array}{l}\text { Predictors } \\
\text { (Constant) }\end{array}$ & $\begin{array}{l}\text { Criminal offences related to the possession of } \\
\text { narcotic or psychotropic substances and their } \\
\text { contraband (misdemeanors) }\end{array}$ & 535.375 & 102.62405 & 8 \\
\hline
\end{tabular}

Table 2. Correlation analysis and model of the statistics of shadow economy power and criminal offence activity variables in 2005-2012

\begin{tabular}{|c|c|c|c|c|c|c|c|c|c|c|c|}
\hline \multirow{3}{*}{ 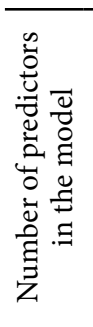 } & \multirow[b]{3}{*}{ Predictors (Constant) } & \multirow{2}{*}{\multicolumn{2}{|c|}{ Correlations }} & \multirow{2}{*}{\multicolumn{4}{|c|}{ Model summary }} & \multicolumn{4}{|c|}{ ANOVA } \\
\hline & & & & & & & & \multicolumn{3}{|c|}{ Sum of squares } & \multirow[b]{2}{*}{ Sig. } \\
\hline & & 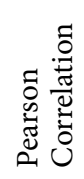 & 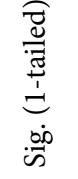 & $\simeq$ & 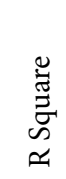 & 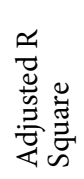 & 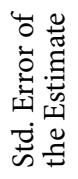 & 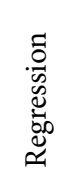 & 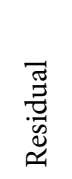 & 吾 & \\
\hline \multirow{2}{*}{2} & $\begin{array}{l}\text { Criminal offences related } \\
\text { to the possession of } \\
\text { narcotic or psychotropic } \\
\text { substances and their } \\
\text { contraband (crimes) }\end{array}$ & 0.60 & 0.06 & \multirow{2}{*}{0.92} & \multirow{2}{*}{0.85} & \multirow{2}{*}{0.79} & \multirow{2}{*}{0.02} & \multirow{2}{*}{0.02} & \multirow{2}{*}{0.00} & \multirow{2}{*}{0.02} & \multirow{2}{*}{0.01} \\
\hline & $\begin{array}{l}\text { Criminal offences related to } \\
\text { the possession of narcotic } \\
\text { or psychotropic substances } \\
\text { and their contraband } \\
\text { (misdemeanors) }\end{array}$ & 0.92 & 0.00 & & & & & & & & \\
\hline
\end{tabular}

Note: Dependent Variable: Power of shadow economy. 
Table 3. Statistics of shadow economy power and criminal offence coefficients in 2005-2012

\begin{tabular}{llccccc}
\hline \multirow{2}{*}{ Model } & \multicolumn{2}{c}{$\begin{array}{c}\text { Unstandardized } \\
\text { coefficients }\end{array}$} & $\begin{array}{c}\text { Standardized } \\
\text { coefficients }\end{array}$ & \multirow{2}{*}{ Sig. } \\
\cline { 2 - 5 } & $\mathrm{B}$ & Std. Error & Beta & & \\
\hline (Constant) & -0.161 & 0.049 & & & -3.273 & 0.022 \\
\hline $\begin{array}{l}\text { Criminal offences related to the possession of } \\
\text { narcotic or psychotropic substances and their } \\
\text { contraband (crimes) }\end{array}$ & 0.000 & 0.000 & 0.042 & 0.191 & 0.856 \\
$\begin{array}{l}\text { Criminal offences related to the possession of } \\
\text { narcotic or psychotropic substances and their } \\
\text { contraband (misdemeanors) }\end{array}$ & 0.000 & 0.000 & 0.896 & & 4.057 & 0.010 \\
\hline
\end{tabular}

Note: Dependent Variable: Power of shadow economy.

Measurement of the convergent validity between criminal offences and the variable of calculated shadow economy power showed that criminal offences related to the possession of narcotic or psychotropic substances and contraband explains a change in the shadow economy power.

During the measurement of convergent validity, there was also an analysis of the distribution of households in the dependence of the households' ability to make ends meet.

Additionally, there was a need to better ascertain the evolution of a household's ability to make ends meet as an index of human resources' living quality. Knowledge of this evolution allowed the identification of this index as one that determined a change in the shadow economy power. During analysis, it was determined that the state of households between 2008 and 2010 became worse (Table 4). In comparison with 2010 and 2011, there was a noticeable stabilization in the state of households. It should be noted that a "bad" state means the sum of the categories "very hard", "hard" and "hard enough".

Table 4. Distribution of households in Lithuania in accordance with a household's ability to make ends meet, $\%^{3}$

\begin{tabular}{lcccc}
\hline & 2008 & 2009 & 2010 & 2011 \\
\hline Very hard & 6 & 10.8 & 13.2 & 12.6 \\
Hard & 22 & 26.2 & 27.1 & 25.2 \\
Hard enough & 54 & 50 & 47.9 & 48.8 \\
Easy enough & 15 & 10.8 & 10.1 & 11.7 \\
Easy, very easy & 3 & 2.1 & 1.8 & 1.7 \\
\hline
\end{tabular}

Source: Lithuanian Department of Statistics (Statistics Lithuania 2013).

A comparison of households' ability to make ends meet with shadow economy power was performed using linear regression analysis (Tables 5, 6 and 7). The coefficient of Pearson correlation obtained (0.988) shows that the estimated variable of shadow economy power is very strongly correlated to the households' ability to make ends meet.

In conclusion, it could be stated that an increase in the shadow economy power not only describes an increase in criminal offences related to the possession of narcotic or psychotropic substances and their contraband, but also to the worsening of the economic condition of a household, which allows stating in general context that the variable created describes the evolution of the shadow economy. 
Table 5. Descriptive statistics of the distribution of households in Lithuania in accordance with a household's ability to make ends meet and the variables of shadow economy power, 2008-2011

\begin{tabular}{lccc}
\hline & Mean & Std. deviation & $\mathrm{N}$ \\
\hline Power of shadow economy & 0.1195 & 0.05217 & 4 \\
households' situation bad, cumulative percent & 85.9500 & 2.71968 & 4 \\
\hline
\end{tabular}

Table 6. Indices of the distribution of households in the Republic of Lithuania in accordance with a household's ability to make ends meet and shadow economy power interdependence and the model's quality, 2008-2011

\begin{tabular}{cccccccc}
\hline & \multicolumn{3}{c}{ Model Summary } & \multicolumn{4}{c}{ ANOVA } \\
\hline \multirow{2}{*}{$\mathrm{R}$} & \multirow{2}{*}{ R square } & $\begin{array}{c}\text { Adjusted } \\
\text { R square }\end{array}$ & $\begin{array}{l}\text { Std. error of } \\
\text { the estimate }\end{array}$ & & \multicolumn{3}{c}{ Sum of squares } \\
\cline { 5 - 7 } & & 0.964 & 0.00991 & Regression & Residual & Total & \\
\hline $0.988^{\mathrm{a}}$ & 0.976 & 0.008 & 0.000 & 0.008 & $0.012^{\mathrm{b}}$ \\
\hline
\end{tabular}

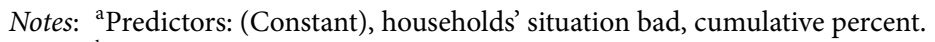

${ }^{\mathrm{b}}$ Dependent Variable: Power of shadow economy.

Table 7. Coefficients of the distribution of households in the Republic of Lithuania in accordance with a household's ability to make ends meet and shadow economy power interdependence, 2008-2011

\begin{tabular}{|c|c|c|c|c|c|c|}
\hline & \multirow[t]{2}{*}{ Model } & \multicolumn{2}{|c|}{$\begin{array}{l}\text { Unstandardized } \\
\text { coefficients }\end{array}$} & \multirow{2}{*}{$\begin{array}{c}\text { Standardized } \\
\text { coefficients }\end{array}$} & \multirow[t]{2}{*}{$\mathrm{t}$} & \multirow[t]{2}{*}{ Sig. } \\
\hline & & $\mathrm{B}$ & Std. Error & & & \\
\hline & (Constant) & -1.509 & 0.181 & & -8.341 & 0.014 \\
\hline 1 & $\begin{array}{l}\text { Households' situation bad, } \\
\text { cumulative percent }\end{array}$ & 0.019 & 0.002 & 0.988 & 9.005 & 0.012 \\
\hline
\end{tabular}

Note: Dependent Variable: Power of shadow economy.

Results for modeling the predictive validity of shadow economy power. The calculation of predictive validity was performed in accordance with the scenario of empirical modeling by applying a methodology of quasi-experimental research. Thus, the researched period was divided into two intervals: experimental and control. Data until the point of the economic development break was attributed to the experimental data, and with reference to them, a prediction was made by applying a trend function. Meanwhile, the data during the period researched after the point of the economic development break was attributed to the control data. Using this data, a comparison of the predictive results obtained by trend projection and control data using a regression method was performed. Such a scenario allows for a savings in time, and there is no need to wait for one or two years until the predicted data can be approved or disapproved. The predictive data is presented in Table 8.

When the shadow economy power variable is predicted for the period 2009 using the polynomial trend order 3 function, it is possible to estimate the power's break point at the end of 2009 and the beginning of 2010. It should be noted that in such circumstances, when the macro-economic development process is only described by the data of four periods, such a prognosis could only be supposed as just valid. The high predictive validity can be confirmed by calculating the bias of approximation (in this case, $\mu_{\text {poly }}=0.000 \%$ ) as well, but in this case, it can be discussed because of the small number of periods as well. From the phenomenology and by using the polynomial trend, there is the possibility to logically predict the power's break point of out of four periods (Fig. 3). 
Table 8 . Results of shadow economy power and shadow economy power change prediction using a trend function

\begin{tabular}{|c|c|c|c|c|c|c|c|c|}
\hline & 2005 & 2006 & 2007 & 2008 & 2009 & 2010 & 2011 & 2012 \\
\hline $\begin{array}{l}x \text { for polynomial trend of shadow } \\
\text { economy power }\end{array}$ & 1 & 2 & 3 & 4 & 5 & 6 & 7 & 8 \\
\hline $\begin{array}{l}x \text { for polynomial trend of shadow } \\
\text { economy power change }\end{array}$ & & 1 & 2 & 3 & 4 & 5 & 6 & 7 \\
\hline $\begin{array}{l}\text { Polynomial trend of shadow } \\
\text { economy power }\end{array}$ & 0.054 & 0.041 & 0.04 & 0.045 & 0.05 & 0.049 & 0.036 & 0.005 \\
\hline $\begin{array}{l}\text { Polynomial trend of shadow } \\
\text { economy power change }\end{array}$ & & -0.241 & -0.02 & 0.135 & 0.224 & 0.247 & 0.204 & 0.095 \\
\hline \multicolumn{3}{|c|}{$\begin{array}{l}\mu \text { for polynomial trend of shadow economy } \\
\text { power, } \%=\mathbf{0 . 0 0 0}\end{array}$} & \multicolumn{6}{|c|}{$\begin{array}{c}\mu \text { for polynomial trend of shadow economy } \\
\text { power change, } \%=\mathbf{0 . 0 0 0}\end{array}$} \\
\hline
\end{tabular}

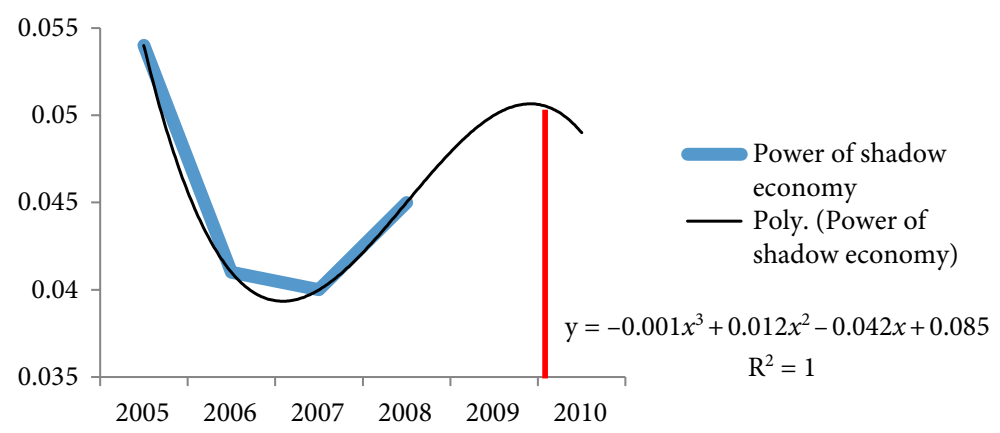

Fig. 3. Dynamics of shadow economy power up through 2008 in Lithuania and its trend

The prognostic model obtained on the basis of the shadow economy power growth rate $\left(\mathrm{GR}=\left(\mathrm{V}_{\text {present }}-\mathrm{V}_{\text {past }}\right) / \mathrm{V}_{\text {past }}\right)$ also indicates a break in the shadow economy's power in 2010. This coincides with the real fact (Fig. 1). Besides this, the visual fact is also confirmed by a bias of approximation close to $0\left(\mu_{\text {poly }}=0.000 \%\right)$, which allows the statement that the estimated variable can be used for the prediction of the macroeconomic situation (Fig. 4).

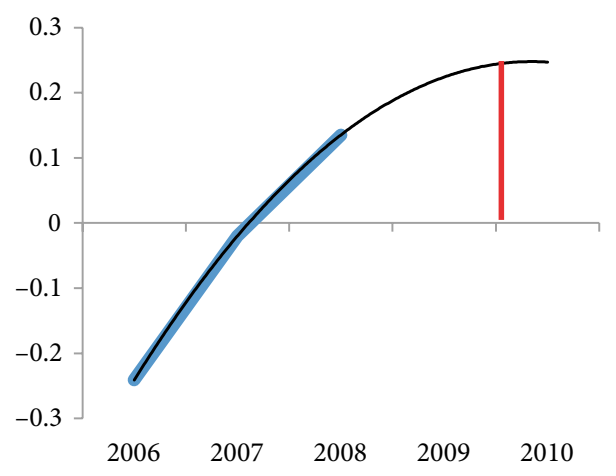

The growth rate of shadow economy power

— Poly. (The growth rate of shadow economy power)$$
\mathrm{y}=-0.033 x^{2}+0.32 x-0.528
$$$$
\mathrm{R}^{2}=1
$$

Fig. 4. Dynamics of the shadow economy power growth rate up through 2008 in Lithuania and its trend 
The predictive validity of the shadow economy power equation was not only verified by the dynamics of the variable values calculated, but also by the reflected content. The results are presented in Tables 9, 10 and 11.

The predictive assessment of shadow economy content was performed using six cases, two of which were intended to assess the compatibility of the shadow economy power variable with the index developed by the Lithuanian Free Market Institute (Zukauskas 2014), and the remaining four measured the capability of the shadow economy power variable to predict criminal offences related to the shadow economy. The highest reliability out of all six cases is in the third case. Here, the dependence was measured between the shadow economy power trend and criminal offences related to the possession of narcotic or psychotropic substances and their contraband (crimes) variable in 2009-2012 (Tables 10 and 11).

The first, second and fourth cases were distinguished by a relatively high correlation with the shadow economy power variable, but due to the small number of periods, the interdependence is not significant, therefore it could only be treated as an existing tendency, but not a rule. In the fifth and sixth cases, the correlation is close to zero, and the quality rates of the regression model show that there is no interdependence between criminal offences related to

Table 9. Descriptive statistics of shadow economy power and its predictors

\begin{tabular}{|c|c|c|c|c|}
\hline & & Mean & $\begin{array}{c}\text { Std. } \\
\text { deviation }\end{array}$ & $\mathrm{N}$ \\
\hline \multirow[b]{2}{*}{ Case 1} & Dependent Variable: Shadow economy LRI, 2009-2011 & 26.33 & 2.89 & 3 \\
\hline & $\begin{array}{l}\text { Predictor: (Constant), Trend of shadow economy power, } \\
\text { 2009-2011 }\end{array}$ & 0.05 & 0.01 & 3 \\
\hline \multirow[b]{2}{*}{ Case 2} & Dependent Variable: Shadow economy LRI, 2009-2011 & 26.33 & 2.89 & 3 \\
\hline & $\begin{array}{l}\text { Predictors: (Constant), Trend of the shadow economy power } \\
\text { growth rate, 2009-2011 }\end{array}$ & 0.52 & 0.19 & 3 \\
\hline \multirow[t]{2}{*}{ Case 3} & $\begin{array}{l}\text { Dependent Variable: Criminal offences related to the possession } \\
\text { of narcotic or psychotropic substances and their contraband } \\
\text { (crimes), 2009-2012 }\end{array}$ & 1789.50 & 391.57 & 4 \\
\hline & $\begin{array}{l}\text { Predictors: (Constant), Trend of shadow economy power, } \\
\text { 2009-2012 }\end{array}$ & 0.04 & 0.02 & 4 \\
\hline \multirow[t]{2}{*}{ Case 4} & $\begin{array}{l}\text { Dependent Variable: Criminal offences related to the possession } \\
\text { of narcotic or psychotropic substances and their contraband } \\
\text { (crimes), 2009-2012 }\end{array}$ & 1789.50 & 391.57 & 4 \\
\hline & $\begin{array}{l}\text { Predictors: (Constant), Trend of the shadow economy power } \\
\text { growth rate, 2009-2012 }\end{array}$ & 0.62 & 0.24 & 4 \\
\hline \multirow[t]{2}{*}{ Case 5} & $\begin{array}{l}\text { Dependent Variable: Criminal offences related to the possession } \\
\text { of narcotic or psychotropic substances and their contraband } \\
\text { (misdemeanors), 2009-2012 }\end{array}$ & 626.75 & 8.81 & 4 \\
\hline & $\begin{array}{l}\text { Predictors: (Constant), Trend of shadow economy power, } \\
\text { 2009-2012 }\end{array}$ & 0.04 & 0.02 & 4 \\
\hline \multirow[t]{2}{*}{ Case 6} & $\begin{array}{l}\text { Dependent Variable: Criminal offences related to the possession } \\
\text { of narcotic or psychotropic substances and their contraband } \\
\text { (misdemeanors), 2009-2012 }\end{array}$ & 626.75 & 8.81 & 4 \\
\hline & $\begin{array}{l}\text { Predictors: (Constant), Trend of the shadow economy power } \\
\text { growth rate, 2009-2012 }\end{array}$ & 0.62 & 0.24 & 4 \\
\hline
\end{tabular}




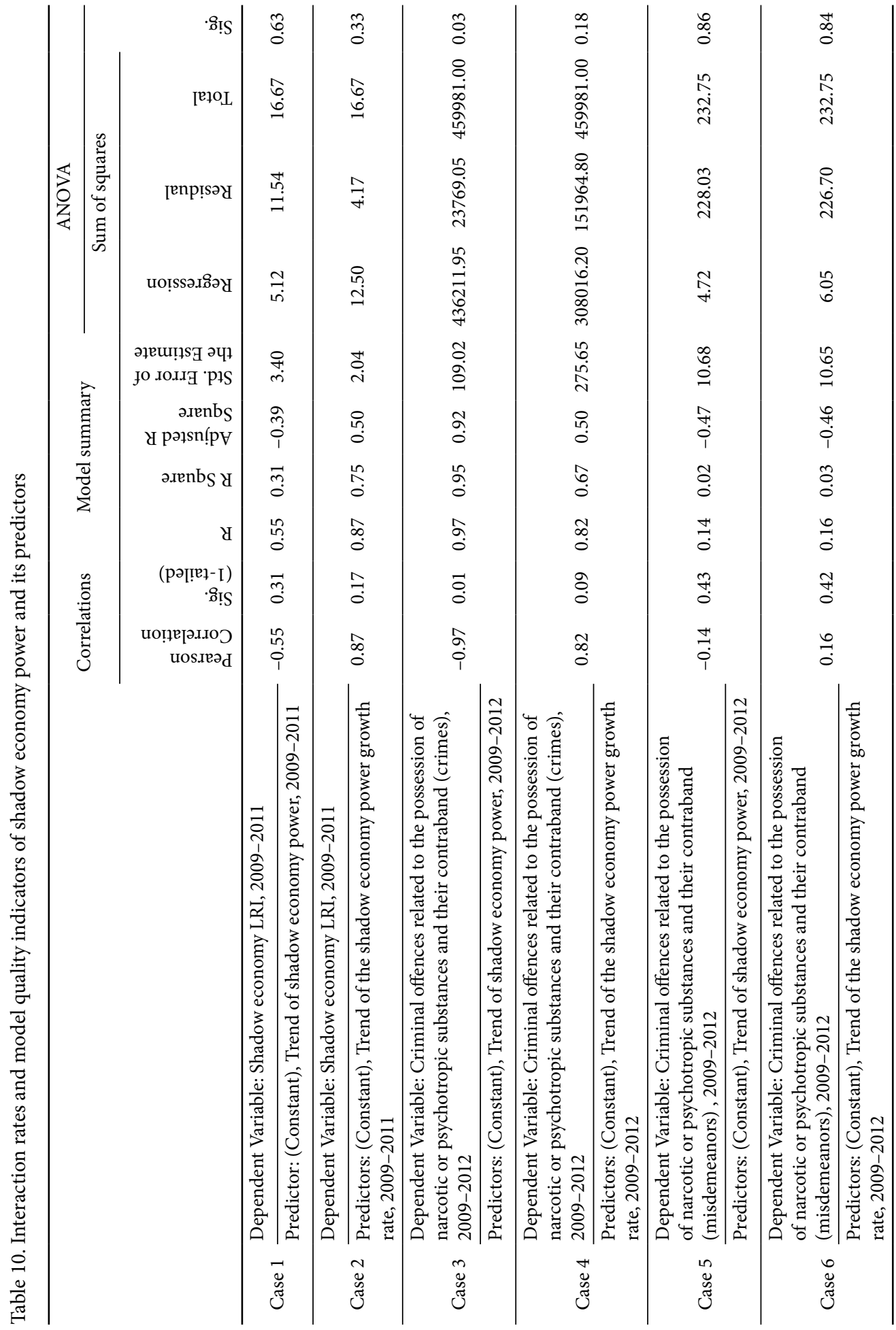


the possession of narcotic or psychotropic substances and their contraband (misdemeanors) and the shadow economy power and its growth rate trends in 2009-2012. That means that the shadow economy power cannot predict the change of this variable.

In conclusion, the results of the shadow economy power's predictive validity show that the variable of shadow economy power can be used for the prediction of shadow economy evolution if the legal basis remains unchanged. However, a limitation of the variable of shadow economy power is that it does not assess the effectiveness of the legal basis and preventive means. Effective means in shadow economy prevention will reduce its rate, but the shadow economy power rate will remain unchanged because it is designed to measure its relation to the shadow economy but not to the shadow economy rate itself.

Table 11. Coefficients of shadow economy power and its predictors

\begin{tabular}{|c|c|c|c|c|c|c|}
\hline & & \multicolumn{2}{|c|}{$\begin{array}{l}\text { Unstandardized } \\
\text { coefficients }\end{array}$} & \multirow{2}{*}{$\begin{array}{c}\begin{array}{c}\text { Standardized } \\
\text { coefficients }\end{array} \\
\text { Beta }\end{array}$} & \multirow{2}{*}{$\mathrm{t}$} & \multirow{2}{*}{ Sig. } \\
\hline & & B & $\begin{array}{l}\text { Std. } \\
\text { Error }\end{array}$ & & & \\
\hline \multirow[t]{2}{*}{ Case 1} & $\begin{array}{l}\text { Predictor: (Constant), Trend of shadow } \\
\text { economy power, 2009-2011 }\end{array}$ & 35.56 & 13.98 & & 2.54 & 0.24 \\
\hline & Dependent Variable: Shadow economy LRI & -204.92 & 307.61 & -0.55 & -0.67 & 0.63 \\
\hline \multirow[t]{2}{*}{ Case 2} & $\begin{array}{l}\text { Predictors: (Constant), Trend of the } \\
\text { shadow economy power growth rate }\end{array}$ & 19.39 & 4.18 & & 4.64 & 0.14 \\
\hline & Dependent Variable: Shadow economy LRI & 13.30 & 7.68 & 0.87 & 1.73 & 0.33 \\
\hline \multirow[b]{2}{*}{ Case 3} & $\begin{array}{l}\text { Predictors: (Constant), Trend of shadow } \\
\text { economy power, 2009-2012 }\end{array}$ & 2425.27 & 118.25 & & 20.51 & 0.00 \\
\hline & $\begin{array}{l}\text { Dependent Variable: Criminal offences } \\
\text { related to the possession of narcotic } \\
\text { or psychotropic substances and their } \\
\text { contraband (crimes), 2009-2012 }\end{array}$ & -18164.90 & 2998.30 & -0.97 & -6.06 & 0.03 \\
\hline \multirow[b]{2}{*}{ Case 4} & $\begin{array}{l}\text { Predictors: (Constant), Trend of the } \\
\text { shadow economy power growth rate, } \\
2009-2012\end{array}$ & 976.25 & 426.79 & & 2.29 & 0.15 \\
\hline & $\begin{array}{l}\text { Dependent Variable: Criminal offences } \\
\text { related to the possession of narcotic } \\
\text { or psychotropic substances and their } \\
\text { contraband (crimes), 2009-2012 }\end{array}$ & 1320.21 & 655.71 & 0.82 & 2.01 & 0.18 \\
\hline \multirow[b]{2}{*}{ Case 5} & $\begin{array}{l}\text { Predictors: (Constant), Trend of shadow } \\
\text { economy power, 2009-2012 }\end{array}$ & 628.84 & 11.58 & & 54.29 & 0.00 \\
\hline & $\begin{array}{l}\text { Dependent Variable: Criminal offences } \\
\text { related to the possession of narcotic } \\
\text { or psychotropic substances and their } \\
\text { contraband (misdemeanors), 2009-2012 }\end{array}$ & -59.76 & 293.67 & -0.14 & -0.20 & 0.86 \\
\hline \multirow[b]{2}{*}{ Case 6} & $\begin{array}{l}\text { Predictors: (Constant), Trend of the } \\
\text { shadow economy power growth rate, } \\
2009-2012\end{array}$ & 623.15 & 16.48 & & 37.80 & 0.00 \\
\hline & $\begin{array}{l}\text { Dependent Variable: Criminal offences } \\
\text { related to the possession of narcotic } \\
\text { or psychotropic substances and their } \\
\text { contraband (misdemeanors), 2009-2012 }\end{array}$ & 5.85 & 25.33 & 0.16 & 0.23 & 0.84 \\
\hline
\end{tabular}




\subsection{Methodology of modeling the shadow economy power interdependence with human capital}

The dependence of shadow economy power on human capital was evaluated using the linear regression method. The method of linear regression was chosen because it allows the determination of which variables of human capital can measure the change in shadow economy power. For evaluation of the interdependence, the variables of the years 2005-2012 were used. The results of the dependence of shadow economy power on human capital are presented in Tables 12 and 13.

In order to determine the interdependence between the shadow economy and human capital, a list of variables was created. The variables of assessment were selected with reference to the methodologies of human capital assessment presented in economic scientific literature and economic logic that allow reflection of the interdependence of Human capital and shadow economy power. The selection of the variables was also determined by their availability in the database of Statistics Lithuania (2013). Thus, the following variables of human capital were used for the research:

- Variables of social development such as demographic changes and risk of poverty. Although the World Economic Forum does not take into account changes in migration and population while calculating HCI, Liudwig et al. (2012), Sadahiro and Shimasawa (2003) and Contreras (2013) have investigated and found that demographic changes have an influence on a country's human capital development. The variable "people at risk of poverty or social separation" does not show the level of receivable income as one aspect of human capital. The variable concerned with poverty and social separation shows people's deprivation, which is closely related to education, poor life quality, state of health and the influence of these factors (Alkire, Santos 2010; Salazar et al. 2013; Parro 2012; Kinsler, Pavan 2011).

Table 12. Descriptive statistics in estimation of the interdependence between shadow economy power and human capital variables for the period of 2005-2012

\begin{tabular}{|c|c|c|c|c|c|}
\hline \multirow{2}{*}{\multicolumn{2}{|c|}{ Variable type }} & \multirow[b]{2}{*}{ Variables } & \multicolumn{3}{|c|}{ Descriptive statistics } \\
\hline & & & Mean & $\begin{array}{c}\text { Std. } \\
\text { deviation }\end{array}$ & $\mathrm{N}$ \\
\hline \multicolumn{6}{|c|}{ Dependent Variable } \\
\hline \multicolumn{3}{|r|}{ Power of shadow economy } & 0.0925 & 0.05232 & 8 \\
\hline \multicolumn{6}{|c|}{ Predictors (Constant) } \\
\hline \multirow{6}{*}{ 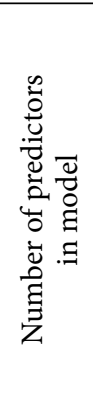 } & 1 & Departed & 99155 & 17284.96141 & 8 \\
\hline & 1 & Foreign direct investment in $\%$ of GDP & 3.6 & 2.21746 & 8 \\
\hline & 1 & $\begin{array}{l}\text { People on the poverty line depending on education, } \\
\text { ISCED97 (level 0-2), age 18-64 }\end{array}$ & 36.7 & 3.30108 & 8 \\
\hline & 1 & $\begin{array}{l}\text { People on the poverty line depending on education, } \\
\text { ISCED97 (level 3-4), age 18-64 }\end{array}$ & 20.1625 & 2.14072 & 8 \\
\hline & 1 & $\begin{array}{l}\text { People on the poverty line depending on education, } \\
\text { ISCED97 (level 5-6), age 18-64 }\end{array}$ & 14.425 & 3.17659 & 8 \\
\hline & 3 & $\begin{array}{l}\text { People on the poverty line depending on education, } \\
\text { ISCED97 (level 0-2), age 18-64 }\end{array}$ & 36.7 & 3.30108 & 8 \\
\hline
\end{tabular}


- Indicator of HC economic development - People on the poverty line depending on education, ISCED97 (level 5-6, age 18-64).

- Indicator of HC economic potential - direct foreign investment as a \% of GDP. Direct foreign investment and human capital directly influence the growth of a country's economy. Moreover, foreign direct investment and human capital are closely interdependent (Miyamoto 2003; Ashraf 2010). An assumption can be made that changes in direct foreign investments may cause an increase or decrease in the shadow economy rate. Table 12 presents descriptive statistics of the variables of shadow economy power and human capital.

Table 13. Coefficients of estimation of the interdependence between the shadow economy power and human capital variables*

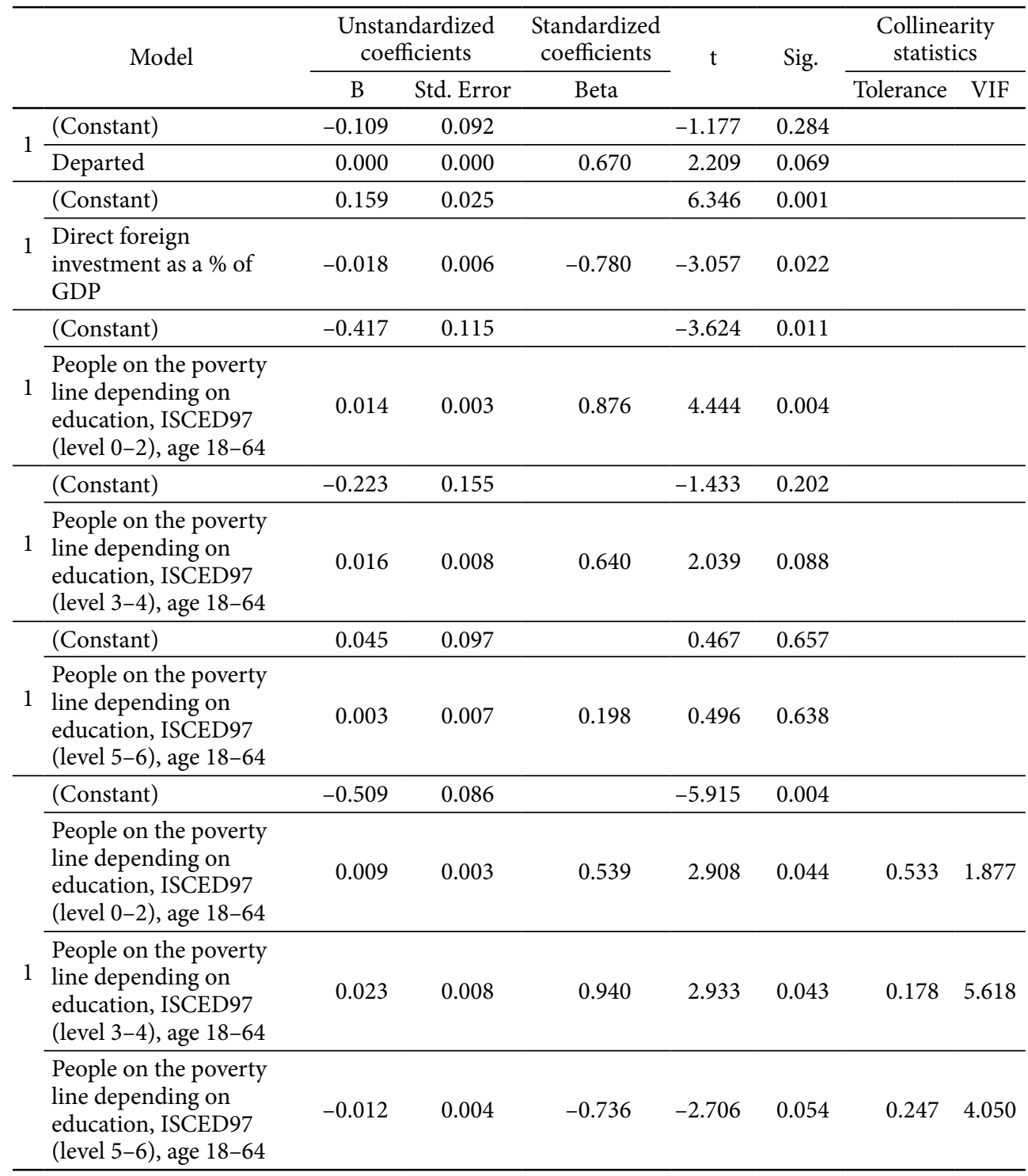

Notes: Dependent Variable: Shadow economy power.

* for the period 2005-2012. 
For the modeling of the shadow economy and human capital interdependence, the variables reflecting human capital were selected and checked. Selection of the variables was performed based on the criteria of regular fact or in cases where a tendency towards interdependence exists.

Five variables of human capital were suitable for the modeling of interdependence, the first four out of five (Table 13) formed independent interdependence models, and the fifth only had meaning as an additive model. Thus there were five models of one-dimensional regression and one model of multi-dimensional regression.

\section{Findings of empirical verification of shadow economy power and its dependence on human capital in Lithuania}

The results of the research on the dependence between the shadow economy power and human capital shows the conclusion that the variables of $\mathrm{HC}$ that were researched, such as direct foreign investment as a \% of GDP and the amount of people on the poverty line depending on education, ISCED97 (level 0-2, age18-64) may influence an increase in shadow economy power.

In the case of direct foreign investment as a \% of GDP, a decrease in foreign investment can be treated as an indicator that describes an increase in shadow economy power. It is important to note that here, direct foreign investment as a variable describes the attractiveness of human capital. Nevertheless, human capital is invested when it is profitable and competitive. Meanwhile, when human capital has no such characteristics, it becomes less valuable and therefore it is less influential. In such cases, presumptions are formed for the development of a shadow economy. This is because people who fall into such a situation will still try to satisfy their consumption needs, though strongly reduced but still topical, which exceed the consumption capability as a rule. It is such circumstances that stimulate the search for cheaper, though more risky, ways of consumption that are the result of the shadow economy in many cases.

The variable that represents people on the poverty line depending on education, ISCED97 (level 0-2), age 18-64 (Table 13) unlike direct foreign investment, directly describes the material situation of human resources, but much like the direct foreign investment, does describe their economic value. In this case, the research showed that the higher the rate of people on the poverty line depending on education, ISCED97 (level 0-2), age 18-64, the higher the power of the shadow economy. This once again confirms the argument that has already been presented that the economic situation of poor people is one of the reasons for an increase in shadow economy power. The statistical quality of the indicators representing people on the poverty line depending on education (ISCED97, level 3-4, level 6) shows that they can only be assessed as variables describing some tendency, therefore the additive model combining the influence of all three on shadow economy power was created. The additive model shows that the most important variable is the amount of people on the poverty line depending on education according to ISCED97 (level 3-4), while the least significant is the variable of people on the poverty line depending on education ascribed to ISCED97 (level 0-2). The indicators for the statistical quality of the latter are the best. 


\section{Conclusions and discussion}

In this paper, we proposed to study the dependence between human capital and the power of the shadow economy. The Lithuanian economy was selected to carry out the study. In Lithuania and throughout the world, the shadow economy, with its reasons and consequences, are constantly being analyzed. Although different researchers apply different evaluation methods, the tendencies of shadow economy change that are explored remain similar. In the case of Lithuania, clear changes in the shadow economy were observed in 2009. Later, the rate of the shadow economy decreased together with the shadow economy power. In evaluating human capital affected by the conditions of the shadow economy, a few deviations could be distinguished.

Firstly, the human capital education level is an important consideration when stating that favorable conditions are formed by the development of the shadow economy. This was confirmed by the modeling of shadow economy power and people on the poverty line according to education based on empirical data.

The concept that there is a weakening dependence between shadow economy probability and people on the poverty line depending on education when the level of education increases is also an important argument from the phenomenological point of view, and can be related to the content of human resources socialization. By stating this, the presumption follows that higher education is related to a better understanding of social order and risk related to the violation of laws. In this context, it is normal that even when the economic situation becomes worse, human resources with a higher education are less influenced towards an increase in consumption value on account of the shadow economy. Moreover, according to the values of the index, human resources with a higher education were less affected by the risk of poverty. Thus, education becomes one of the presumptions for human capital to reach a level of better economic welfare and decreased poverty risk in the conditions of the shadow economy.

Secondly, an increase in the shadow economy increases shadow unemployment and vice versa. In the conditions of the shadow economy, part of the human capital goes over to the shadow economy where it uses its own capabilities to create productivity that is unaccounted for. Along with this, the migration of human capital to the shadow economy does not reflect the real value of human capital, and this, in turn, decreases the attraction of direct foreign investment.

Finally, this paper only researched the interdependence of the shadow economy and human capital in trying to identify the most sensitive constituents of human capital that could reflect this interdependence. The direction of further research should be oriented towards the problem of a deeper analysis of the impact of the shadow economy on human capital by researching the influence of the separate factors of the shadow economy on the variables of human capital.

\section{References}

Alkire, S.; Santos, M. E. 2010. Acute multidimensional poverty: a new index for developing countries, OPHI Working paper 38(2) [online], [cited 26 May 2013]. Available from Internet: http://www.ophi.org. uk/wp-content/uploads/ophi-wp38.pdf

Alm, J.; Torgler, B. 2006. Culture differences and tax morale in the United States and in Europe, Journal of Economic Psychology 27(2): 224-246. http://dx.doi.org/10.1016/j.joep.2005.09.002 
Arendt, J. N. 2012. The demand for health care by the poor under universal health care coverage, Journal of Human Capital 6(4): 316-335. http://dx.doi.org/10.1086/669139

Ashraf, A. M. 2010. FDI, local financial markets, employment and poverty alleviation, MPRA Paper 29717. University Library of Munich, Germany.

Bajada, C.; Schneider, F. 2009. Unemployment and the shadow economy in the OECD, Review Economique 60(4): 1011-1033.

Blair, M. M. 2012. An economic perspective on the notion of "human capital", in The Oxford handbook of human capital. $1^{\text {st }}$ ed. Oxford University Press, 49-70.

Charles, A.; Fontana, G.; Srivastava, A. 2011. India, China and the East Asian miracle: a human capital development path to high growth rates and declining inequalities, Cambridge Journal of Regions, Economy and Sociology 4(1): 29-48 [online], [cited 15 May 2013]. Available from Internet:

http://cjres.oxfordjournals.org/content/4/1/29.abstract?sid=f21c1997-02cd-49ea-b024-7d6fbd5aa726

Ciegis, R.; Ramanauskiene, J.; Startiene, G. 2009. Theoretical reasoning of the use of indicators and indices for sustainable development assessment, Inzinerine Ekonomika - Engineering Economy (3): 33-40.

Contreras, S. 2013. The influence of migration on human capital development, International Economic Journal 27(3): 365-384. http://dx.doi.org/10.1080/10168737.2012.659277

Edwards, B. K.; Flaim, S. J. 2008. Measuring and integrating the shadow economy: a sector-specific approach [online], [cited 14 January 2013]. Available from Internet: http://www.defcon.org/images/defcon-16/ dc16-presentations/defcon-16-edwards.pdf

Enste, D. H. 2010. Shadow economy - the impact of regulation in OECD-countries, International Economic Journal 24(4): 555-571. http://dx.doi.org/10.1080/10168737.2010.525996

Gasik, M. 2011. GDP per capita varied by more than six to one across the EU in 2010, EUROSTAT, Statistics in focus 64 [online], [cited 14 January 2013]. Available from Internet: http://epp.eurostat.ec.europa. eu/cache/ITY_OFFPUB/KS-SF-11-064/EN/KS-SF-11-064-EN.PDF

Gillman, M.; Kejak, M. 2014. Tax evasion, human capital, and productivity-induced tax rate reduction, Journal of Human Capital 8(1): 42-79. http://dx.doi.org/10.1086/675328

Gomis-Porqueras, P.; Peralta-Alva, A.; Waller, Ch. 2014. The shadow economy as an equilibrium outcome, Journal of Economic Dynamics and Control 41: 1-19. http://dx.doi.org/10.1016/j.jedc.2014.02.006

Hansen, C. W. 2013. Health and development: a neoclassical perspective, Journal of Human Capital 7(3): 274-295. http://dx.doi.org/10.1086/674076

Kanao, K.; Hamori, S. 2010. The size of the underground economy in Japan, Economy Bulletin (1): 903-912.

Kinsler, J.; Pavan, R. 2011. Family income and higher education choices: the importance of accounting for college quality, Journal of Human Capital 5(4): 453-477. http://dx.doi.org/10.1086/663649

Krumplytė, J. 2008. Šešèlinès ekonomikos samprata ir priežasčių analizè, Ekonomika ir vadyba: aktualijos ir perspektyvos 4(13): 238-250 (in Lithuanian).

Krumplyte, J.; Samulevicius, J. 2010. Complex research on undeclared work: theoretical aspects and empirical application in Lithuania, Inzinerine Ekonomika - Engineering Economy (3): 283-294.

Liepe, Z. 2013. Methodology of human capital evaluation system in macro level, in Proceedings of the 1st AARESOC International Conference on Business and Management, 5-7 June 2013, Izmir, Turkey.

Liudwig, A.; Scheikle, T.; Vogel, E. 2012. Demographic change, human capital and welfare, Review of Economic Dynamics 15(1): 94-107. http://dx.doi.org/10.1016/j.red.2011.07.001

Miyamoto, K. 2003. Human capital formation and foreign direct investment in developing countries, Working Paper No. 211. OECD Development Centre [online], [cited 16 December 2012]. Available from Internet: http://www.oecd.org/ dev/5888700.pdf

Nafukho, F. M.; Hairiston, N. R.; Brooks, K. 2004. Human capital theory: implications for human resource development, Human Resource Development International 7(4): 545-551.

http://dx.doi.org/10.1080/1367886042000299843 
Okuneviciute Neverauskiene, L.; Pocius, A. 2011. Trends of hidden employment in Lithuania and problems in methodical calculation, Technological and Economic Development of Economy 17(3): 484-500. http://dx.doi.org/10.3846/20294913.2011.603176

Operational programme for the Economical Growth for 2007-2013 [online]. 2007 [cited 16 December 2012]. Available from Internet: http://www.esparama.lt/ES_Parama/strukturines_paramos_2007_1013m. medis/titulinis/files/2VP_EA_2007-07-05.pdf

Oxford Dictionary of English. 2005-2011. Version 2.2.1 (143.1). Apple Inc.

Parro, F. 2012. International evidence on the gender gap in education over the past six decades: a puzzle and an answer to it, Journal of Human Capital 6(2): 150-185. http://dx.doi.org/10.1086/666849

Perrons, P. 2012. Regional performance and inequality: linking economic and social development through a capabilities approach, Cambridge Journal of Regions, Economy and Sociology 5(1): 15-29 [online], [cited 16 June 2013]. Available from Internet: http://cjres.oxfordjournals.org/content/5/1/15.full. pdf + html?sid=f21c1997-02cd-49ea-b024-7d6fbd5aa726

Sadahiro, A.; Shimasawa, M. 2003. The computable overlapping generations model with endogenous grow mechanism, Economic Modelling 20(1): 1-24. http://dx.doi.org/10.1016/S0264-9993(01)00082-7

Sakalas, A.; Liepe, Z. 2013. Human capital system evaluation in the context of the European Union countries, Inzinerine Ekonomika - Engineering Economy 24(3): 226-233.

Salazar, R. C. A.; Diaz, B. Y.; Pinzon, R. P. 2013. A counting multidimensional poverty index in public policy context: the case of Colombia, OPHI Working Paper 62 [online], [cited 10 September 2013]. Available from Internet: http://www.ophi.org.uk/wp-content/uploads/ophi-wp-62.pdf

Schneider, F. 2010. The shadow economy in Europe [online], [cited 15 September 2013]. Available from Internet: http://media.hotnews.ro/ media_server1/document-2011-05-8-8602544-0-shadow.pdf

Schneider, F.; Enste, D. 2002. Hiding in the shadow: size, causes and consequences, The Journal of Economic Literature (1): 77-114.

Schneider, F.; Williams, C. C. 2013. Shadow economy [online]. IEA, the Institute of Economic Affairs [cited 10 September 2013]. Available from Internet: http://www.iea.org.uk/sites/default/files/publications/ files/IEA\%20Shadow\%20Economy\%20web\%20rev\%207.6.13.pdf

Sharpe, M. E. 2007. What is the underground economy?, The Japanese Economy (34): 7-19.

Škare, M. 2011. How important is human capital for growth in reforming economies?, Technological and Economic Development of Economy 17(4): 667-687. http://dx.doi.org/10.3846/20294913.2011.635221

Startiené, G.; Trimonis, K. 2010. Causes and consequences of non-observed economy, Economy and Management (15): 275-280.

Statistics Lithuania [online]. 2013 [cited 15 June 2013]. Available from Internet: http://www.osp.stat.gov. lt/en/web/guest/statistiniu-rodikliu-analize1

Tafenau, E.; Schneider, F.; Herwatz, H. 2010. One share fits all?. Regional variations in the extent of shadow economy in Europe, International Economic Journal 24(4): 629-636. http://dx.doi.org/10.1080/10168737.2010.526010

Torgler, B. 2003. To evade taxes or not to evade: that is the question, The Journal of Socio-Economics 32(3): 283-302. http://dx.doi.org/10.1016/S1053-5357(03)00040-4

Williams, C. C.; Nadin, S. 2012. Tackling the hidden enterprise culture: government policies to support the formalization of informal entrepreneurship, Entrepreneurship and Regional Development 24 (9/10): 895-915. http://dx.doi.org/10.1080/08985626.2012.742325

World Economic Forum. 2013. The Human Capital Report [online], [cited 20 June 2013]. Available from Internet: http://www3.weforum.org/docs/WEF_HumanCapitalReport_2013.pdf

Zukauskas, V. 2014. A survey of the Lithuanian economy, 2013/2014 (1) [online]. Lietuvos laisvosios rinkos institutas [cited 07 February 2014]. Available from Internet: http://files.lrinka.lt/LET2013_2014_1/ LET32.pdf 
Rūta ČIUTIENĖ is a Doctor of social sciences. Doctor degree was earned at ISM University of Management and Economics (Lithuania) in 2006. The topic of doctoral dissertation - "Coordination of Employees and Organizations Interests in Career Development". She is professor at the School of Economics and Business, Kaunas University of Technology, since 2013 September - coordinator of Project Management Master programm, since 2012 - manager of team of scientific research which is funded by Institutional scientific research program "Challenges of Lithuanian economy's long-term competitiveness" project management Current fields of scientific interests - Project management, human resources management, human capital, career management problems.

Evelina MEILIENĖ is a Doctor of social sciences. Doctor degree was earned at Kaunas University of Technology (Lithuania) in 2008. The topic of doctoral dissertation - "Evaluation of industry's export competitiveness of the state in transition". She is assoc. professor at the School of Economics and Business, Kaunas University of Technology, head of Development projects department. Current fields of scientific interests - Project management, project risk management.

Asta SAVANEVIČIENĖ is a doctor of social science (management and administration). Doctor degree was earned at Kaunas University of Technology and Vytautas Magnus University (Lithuania) in 2000. The topic of habilitation procedure (2005) - HRM Aspects of Business Cooperation in the Context of Globalization. She is professor at the School of Economics and Business, Kaunas University of Technology, Head of Management department. Current fields of scientific interests - Strategic human resource management, Competence management.

Sigitas VAITKEVIČIUS, PhD. Professor at School of Economics and Business, Kaunas University of Technology. Current fields of scientific interests - research methodology, business economics and management. 